\title{
Joanna Małecka
}

\section{Zatrudnienie i wartość dodana w małych i średnich przedsiębiorstwach w Polsce i Unii Europejskiej}

Kody JEL: L11, L25, M51, O12, O52

Słowa kluczowe: MSP, wielkość przedsiębiorstwa, zatrudnienie, wartość dodana, UE, Polska

Streszczenie. W artykule podjęto próbę zaprezentowania polskich mikro, małych i średnich przedsiębiorstw w odniesieniu do sytuacji przedsiębiorców działających na terenie krajów należących do Unii Europejskiej. W wymiarze makroekonomicznym, rola i znaczenie całego sektora MSP ciągle rośnie. Polska coraz dynamiczniej i skuteczniej osiąga wskaźniki wyznaczane przez średnie osiągane w UE-28. Wkład MSP w tworzenie PKB, nieustanna fluktuacja ich liczby, produktywności, a także rosnąca aktywność międzynarodowa, przyczyniają się do powstawania coraz bardziej szczegółowych analiz, umożliwiających wyznaczenie kierunków rozwoju poszczególnych branż i przedsiębiorstw tej wielkości. Sektor MSP szczególnego wymiaru nabiera w momencie badania liczby osób, którym zapewnia miejsca pracy i wytwarzanej przez nie wartości dodanej: dotyczy ponad $6 \mathrm{mln}$ z $9 \mathrm{mln}$ pracujących W gospodarce polskiej. W artykule zaprezentowano kształtowanie się wielkości zatrudnienia i wartości dodanej w MSP w Unii Europejskiej i Polsce w 2014 roku.

\section{Wprowadzenie}

Ostatnie lata charakteryzują się pewną niestabilnością i turbulencją, co znalazło swoje odzwierciedlenie również w sektorze MSP. Analiza danych 
dotyczących wyników ekonomicznych małych i średnich przedsiębiorstw, potwierdza ich zdolności do przetrwania i szybkiego przystosowywania się do zmiennych sytuacji rynkowych (Łuczka 2013; Łukasik 2010; Jaworski 2010, PARP 2011-2015). Z załamania koniunktury w 2009 roku, większość z mniejszych podmiotów wyszła pomyślnie, między innymi dzięki stałości reguł wpisanych $\mathrm{w}$ właścicielski schemat zarządzania biznesem, głównie oparty na niechęci do finansowania zewnętrznego (Brealey, 1999; Łuczka 2013; Kołosowska, 2013). Wkład tego sektora w PKB, stanowiący niezaprzeczalną wartość dla całej krajowej gospodarki, wzmacnia zapewnianie ponad $6 \mathrm{mln}^{1}$ miejsc pracy (GUS, 2015). Z jednej strony brak innowacyjności w znaczącym stopniu przyczynia się do braku dynamicznego rozwoju tego sektora, z drugiej strony stanowi pewnego rodzaju zabezpieczenie, które pozwala przetrwać i być konkurencyjnym w czasie kryzysu, szczególnie wobec dużych przedsiębiorstw (Łuczka, 2001). Coraz częściej i chętniej osoby zarządzające tym sektorem sięgają po rozwiązania proponowane przez państwo, na przykład Państwowa Agencja Rozwoju Przedsiębiorczości pełni patronat nad programami dającymi możliwości wspierania potencjału badawczo-rozwojowego i innowacyjnego małych i średnich firm. Niektóre programy ${ }^{2} \mathrm{w}$ sposób szczególny traktują innowacyjne przedsięwzięcia biznesowe, które mają przyczyniać się do umiędzynarodowienia rodzimych przedsiębiorstw. Na pomoc mogą liczyć również te z przedsiębiorstw, które będą potrzebować dodatkowego wsparcia otoczenia biznesowego w zakresie doradztwa finansowego (PARP, 2013).

Zmiany zachodzące $\mathrm{w}$ gospodarce i poszczególnych podmiotach gospodarczych, można zaobserwować w bilansach przedsiębiorstw (Bielawska, 2001; Duliniec, 2011; Grzywacz, 2012). Tylko w 2012 roku, pogorszenie jakości kredytów udzielanych przez banki sektorowi przedsiębiorstw, znalazło swoje odzwierciedlenie w znaczącym przyroście należności zagrożonych wszystkich przedsiębiorstw. W samym sektorze MSP nastąpił wzrost udziału kredytów zagrożonych z 12,3\% do 13,1\% (PARP, 2013; UNKF, 2013). Tempo wzrostu wartości kredytów inwestycyjnych spadło do $2 \%$ porównu-

\footnotetext{
${ }^{1}$ Obecna liczba ludności Polski wynosi 38,5 mln (38 478 602) - na podstawie bilansu ludności według stanu w dniu 21.12.2014 r., na bazie Narodowego Spisu Powszechnego Ludności i Mieszkań 2011 r., w przeliczeniu na podział terytorialny obowiązujący od 1.01.2015 r.; liczbę pracujących stanowi 8898898 na dzień 31.12.2013 r.

${ }^{2}$ Nowe programy finansowane są ze środków unijnych oraz budżetu państwa w programach przypadających na lata 2014-2020. Najwięcej środków zostanie przeznaczonych w ramach Programu Operacyjnego Inteligentny Rozwój oraz programu Operacyjnego Polska Wschodnia na rozwój technologiczny i innowacyjność przedsiębiorstw oraz wsparcie badań naukowych. Regionalne programy operacyjne będą głównie wspomagać zwiększenie konkurencyjności MSP (również PO IR oraz PO PW). Pogram Operacyjny Wiedza Edukacja Rozwój (PO WER) ma wspomagać adaptacyjność firm i rozwój uczenia się przez całe życie.
} 
jąc $\mathrm{r} / \mathrm{r}$, wobec $23 \% \mathrm{w}$ poprzednim roku. Jedyny wzrost (o $7 \% \mathrm{r} / \mathrm{r}$ ) zanotowały kredyty obrotowe, co świadczy o problemach finansowych i próbie pokrycia ich w kwestiach dotyczących bieżącej płynności przedsiębiorstw. W 2014 roku najwięcej udzielono kredytów operacyjnych, następnie inwestycyjnych, na nieruchomości i innych, z których 175,7 mld zł, trafiło do sektora MSP. Rok ten skutkował również wzrostem PKB o 3,4\% r/r (w strefie euro o $0,9 \% \mathrm{r} / \mathrm{r}$ ), co spowodowało dwukrotne zwiększenie aktywności gospodarczej wśród MSP w Polsce, do którego przyczynił się głównie popyt krajowy (wzrost o 4,9\% r/r) oraz wzrost dynamiki polskiego eksportu $(5,7 \%$ r/r) (PARP, 2015). Zaznaczyć również należy, że mimo działań destabilizacyjnych, konfliktu na Ukrainie oraz rosyjskiego embarga na eksport polskiej żywności, rodzime małe i średnie przedsiębiorstwa utrzymały dynamikę inwestycji na wysokim poziomie, wykorzystując swoje moce wytwórcze i możliwości finansowe. Zgodnie z raportem NBP z lipca 2015 roku, zaobserwowano również wzrost dynamiki inwestycji publicznych, któremu sprzyjał wzrost inwestycji samorządów lokalnych (NBP, 2015).

Aprecjację znaczenia tego sektora dla gospodarki można zauważyć analizując rodzaje branż, które reprezentują przedsiębiorcy MSP. Zajmując się tak naprawdę każdą dziedziną gospodarczą, od tradycyjnych wyrobów żywnościowych, po wysokiej klasy wyposażenie, proponując swoje produkty lub usługi $\mathrm{w}$ jednostkowych punktach lub wysoce wyspecjalizowanych sieciach, współpracując zarówno z pojedynczym odbiorcą, jak i wysyłając swoje produkty na export (Muller i in., 2015), przedstawiciele MSP stają się wszechobecni. Stanowią 99,8\% wszystkich przedsiębiorstw niefinansowych w UE-28 (Muller i in., 2015). Blisko 93\% z nich to mikroprzedsiębiorstwa. W głównej mierze ich działalność można zaobserwować w pięciu sekcjach: handlu hurtowym i detalicznym ${ }^{3}$, przetwórstwie przemysłowym ${ }^{4}$, budownictwie ${ }^{5}$, działalności usługowej i wspierającej ${ }^{6}$ i działalności związanej z zakwaterowaniem i usługami gastronomicznymi ${ }^{7}$. Ponad $4 / 5$ wszystkich pracujących, zatrudnionych jest $\mathrm{w}$ budownictwie, generując tym samym podobną wartość dodaną sektora, a 2/3 wytwarzane jest przez firmy z branży hurtowej i sprzedaży detalicznej. Wszystkie wiodące pięć sekcji wpływają w znaczący sposób na wielkość liczby zatrudnionych, która w UE-28 wynosi 70\% wszystkich pracujących. Coraz większym zainteresowaniem cieszy się rynek nieruchomości, który z roku na rok przybiera na znaczeniu wewnątrz sekto-

\footnotetext{
${ }^{3}$ Sekcja G polskiej klasyfikacji PKD: handel hurtowy i detaliczny; naprawa pojazdów samochodowych, włączając motocykle.

${ }_{5}^{4}$ Sekcja D polskiej klasyfikacji PKD.

${ }^{5}$ Sekcja F polskiej klasyfikacji PKD.

${ }^{6}$ Sekcja N polskiej klasyfikacji PKD.

${ }^{7}$ Sekcja I polskiej klasyfikacji PKD.
} 
ra, osiągając coraz lepsze statystyki w udziale zarówno zatrudnienia, jak i wartości dodanej. Mimo i tak znaczących osiągnięć, MSP w UE-28, wśród przedsiębiorstw niefinansowych, zatrudnia o wiele mniej osób niż w pozostałych krajach Europy (Muller i in., 2015) ${ }^{8}$. W 2014 roku, zatrudnienie w sektorze MSP w krajach należących do Unii wzrosło o 1,2\%, zwiększając wartość dodaną o $3,3 \% \mathrm{w}$ relacji z poprzednim rokiem, w którym to wartość dodana wzrosła o 1,6\% a liczba osób zatrudnionych w MSP spadła o 0,5\%. Liczba przedsiębiorstw aktywnych w tym sektorze ciągle rośnie, co pozwala optymistycznie spojrzeć na możliwości przekształcania mikroprzedsiębiorstw w firmy małe, małych w średnie - a tych w duże w kolejnych latach ich działalności.

Struktura kapitału w przedsiębiorstwie, koszt jego pozyskania i wycena wartości od zawsze stanowiły temat rozważań podejmowany w literaturze przedmiotu (Modigliani i Miller, 1958; Dębski, 2014), podobnie jak cykl życia firmy i sposoby finansowania towarzyszące każdej fazie rozwoju (Quinn i Cameron, 1983; Scott i Bruce, 1987; Churchill i Lewis, 1983). Małe i średnie przedsiębiorstwa preferują zawsze wewnętrzne źródła finansowania, czemu sprzyja napotykana dyskryminacja kredytowa, związana z mniej korzystnymi warunkami (wyższe marże, wymagania dotyczące dodatkowych zabezpieczeń, podlegają dokładniejszej kontroli) przyznawania kredytów bankowych (Bielawska, 2005; Łuczka, 2013). Dzięki temu coraz częściej sięgają po nowoczesne instrumenty finansowe oferowane przez rynki kapitałowe (m.in.: NewConnect, Start-up, Capital Venture, Catalyst a nawet AIM). Polska struktura działalności gospodarczej ciągle się zmienia, a statystyki w dość jasny sposób wyznaczają kierunek ich rozwoju, szczególnie w dwóch badanych wskaźnikach: zatrudnieniu i wartości dodanej.

\section{Zatrudnienie i wartość dodana MSP w Unii Europejskiej i Polsce}

Wśród przedsiębiorstw niefinansowych w 2014 roku w UE-28 było 22,3 mln aktywnych podmiotów gospodarczych, należących do grupy małych i średnich przedsiębiorstw. Blisko 58\% wygenerowanej przez nie wartości dodanej stanowi 3,7 bilionów EUR. Mikroprzedsiębiorstwa reprezentują blisko $93 \%$ wszystkich aktywnych przedsiębiorstw, małe ponad 6\% a średnie $1 \%{ }^{9}$ (rys. 1) (Muller i in., 2015). Najwięcej osób w Unii Europejskiej pracuje w mikroprzedsiębiorstwach - ponad $29 \%$.

\footnotetext{
${ }^{8}$ Kraj wiodący gospodarczo, za który uważa się USA prezentuje statystyki odwrotne: liczba zatrudnionych osób w tym kraju w sektorze MSP jest o 15\% niższa niż w UE-28.

${ }^{9} \mathrm{Z}$ wyłączeniem przedsiębiorstw reprezentujących: usługi finansowe, instytucje rządowe, sektor edukacji, zdrowia, rolnictwa oraz rybactwa.
} 


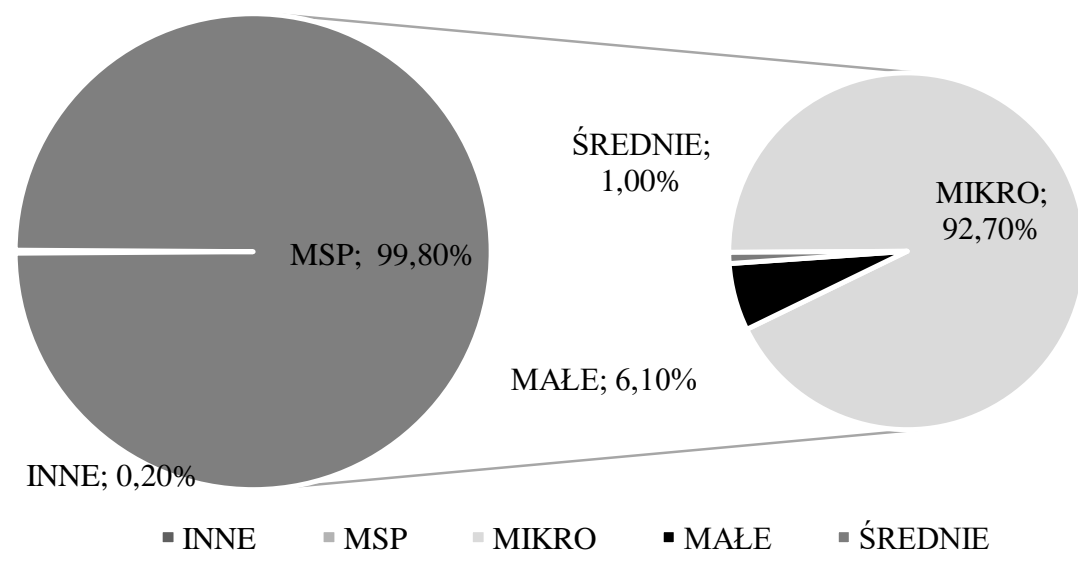

Rysunek 1. Liczba MSP w UE-28 w 2014 roku

Źródło: opracowanie własne na podstawie danych Eurostat.

Małe i średnie przedsiębiorstwa zatrudniały w 2014 odpowiednio ponad: $20 \%$ i $17 \%$ wszystkich pracujących ${ }^{10}$. Wartość dodana wygenerowana przez ten sektor ma jednak inną kolejność pod względem udziału: mikrofirmy - ponad $21 \%$, średnie przedsiębiorstwa dokładnie: $18,5 \%$, małe $18,2 \%$ (rys. 2).

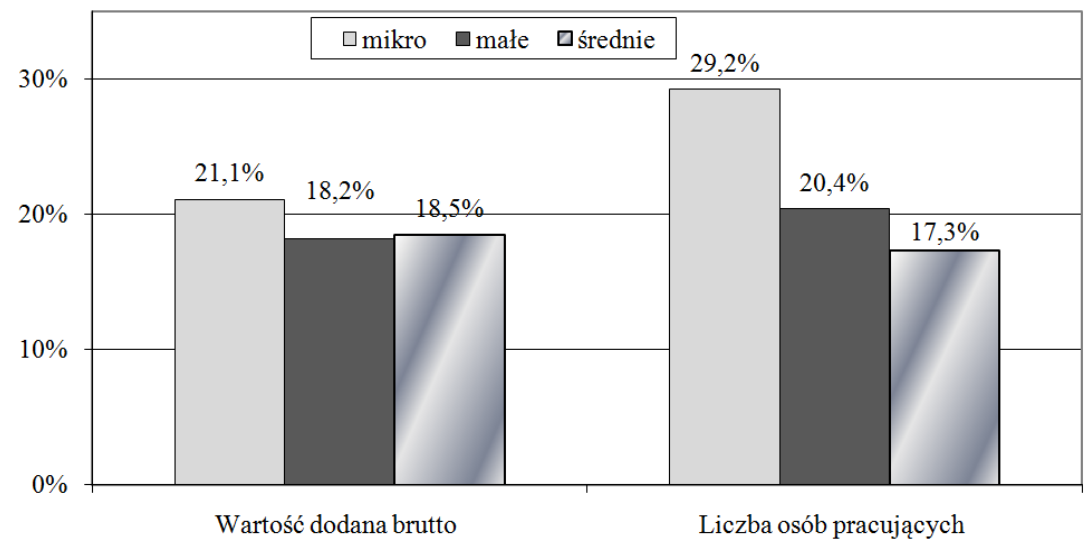

Rysunek 2. Udział wartości dodanej i zatrudnienia w UE-28 w 2014 roku Źródło: opracowanie własne na podstawie danych Eurostat.

\footnotetext{
${ }^{10}$ Zgodnie z danymi raportu przygotowanego dla Komisji Europejskiej w listopadzie 2014 r., ostatnim rokiem, w którym były dostępne dane dotyczące samozatrudnienia był 2012 r., w którym to przedsiębiorcy stanowili 59\% wszystkich firm działających w UE.
} 
Polska wraz z Chorwacją Czechami, Grecją, Węgrami, Włochami, Portugalią, Słowacją, Słowenią, Hiszpanią a także Francją ${ }^{11}$ i Belgią zalicza się do krajów, w których większą rolę niż w innych państwach UE-28 odgrywają mikro i małe przedsiębiorstwa (Muller i in., 2015). Jednocześnie w Czechach, na Węgrzech, w Polsce i Słowacji liczba średnich przedsiębiorstw jest wyższa niż średnio w Unii Europejskiej (rys. 3, 4).

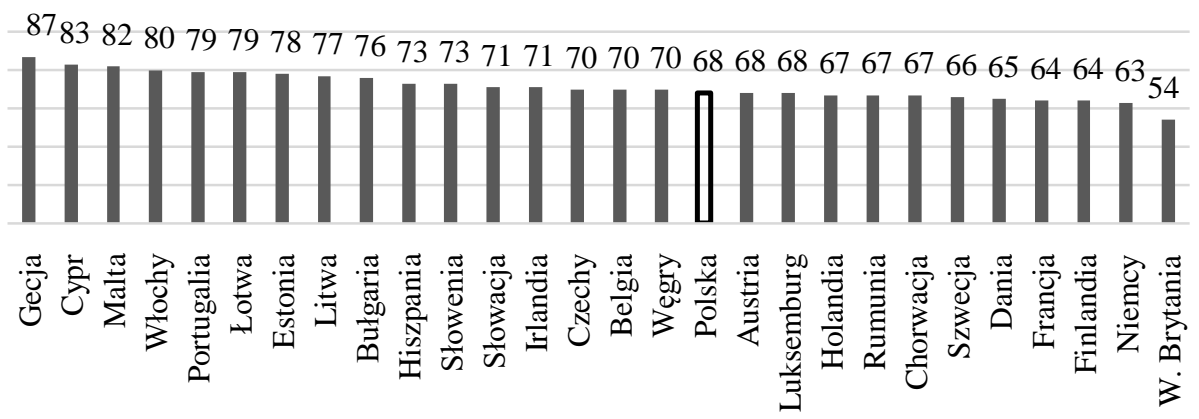

Rysunek 3. Udział osób zatrudnionych w krajach UE-28 w sektorze MSP w 2014 roku (w \%)

Źródło: opracowanie własne na podstawie Muller i in., 2015.

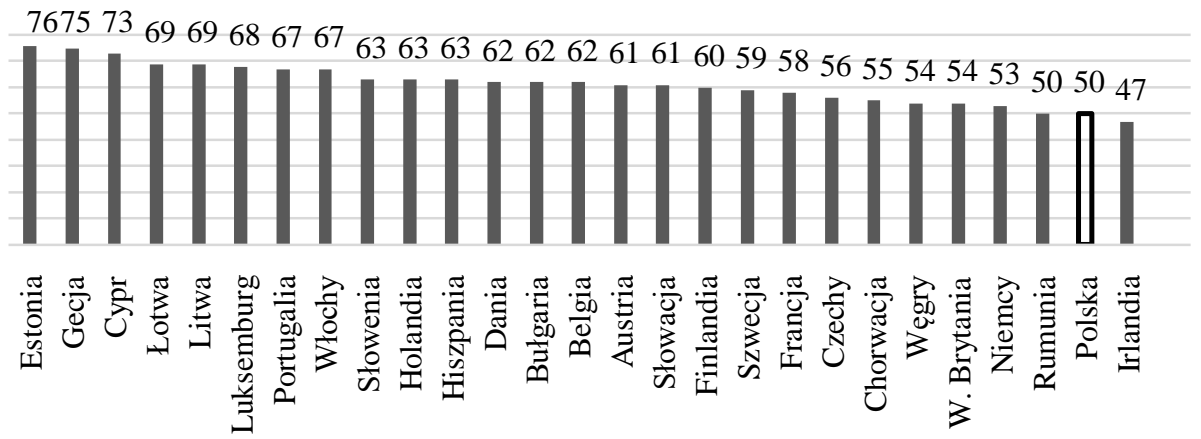

Rysunek 4. Udział wartości dodanej w krajach UE-28 w sektorze MSP w 2014 roku (w \%)

Źródło: opracowanie własne na podstawie Muller i in., 2015.

Na szczególną uwagę zasługują MSP działające w Luksemburgu, który będąc w czołówce generowania wartości dodanej (siódme miejsce w EU-28 w 2014 r.), jednocześnie zatrudniają mniej ludzi niż średnia unijna, zarówno

\footnotetext{
${ }^{11}$ Francja ma wyższą od średniej europejskiej liczbę małych przedsiębiorstw i niższą średnich firm.
} 
wśród mikro, małych jak i średnich firm. Efektywność osiągana dzięki takim wynikom, stawia to państwo na jednym z pierwszych miejsc w Unii. Pozostałe kraje (LT, EE, LV, PT, IT, MT, CY, EL) osiągają najwyższe wyniki wartości dodanej, zapewniając posady większej części populacji pracujących w każdym z analizowanych krajów, przy czym Cypr, Malta i Holandia zatrudniają liczę pracujących poniżej średniej unijnej wśród małych, a powyżej wśród średnich przedsiębiorstw. Warto wyróżnić Bułgarię, która osiągając wartość dodaną tożsamą ze średnią unijną, angażuje o wiele więcej osób w mikro, małych i średnich przedsiębiorstwach. Polska należy do grupy krajów, w których w sektorze MSP pracuje większość populacji zatrudnionych $-68 \%$, jednakże wytwarzana przez nich wartość dodana jest jedną z najniższych w UE- $28-50 \%$ (wykres 3,4 ).

W Polsce działa 1,79 mln przedsiębiorstw niefinansowych ${ }^{12}$ (GUS, 2013), co stanowi nieco ponad 8\% wszystkich przedsiębiorstw działających w UE-28. Klasyfikuje to Polskę na szóstym miejscu, zaraz po Włoszech, Francji ${ }^{13}$, Hiszpanii, Niemczech i Wielkiej Brytanii. 99,8\% przedsiębiorstw to mikro, małe i średnie przedsiębiorstwa co oznacza taki sam udział ich liczby zarówno w kraju, jak i w Unii. Dokładnie 1643186 podmiotów osobowości fizycznej i 148556 o osobowości prawnej określa wewnętrzną strukturę sektora, w której górują mikroprzedsiębiorstwa: prawie $96 \%$, małe - ponad 3\% i średnie - niespełna 1\% (rys. 5). Oznacza to, że w Polsce mamy o ponad 3\% więcej mikroprzedsiębiorstw oraz mniej małych - o prawie 3\% (Małecka, 2015b). Liczbę średnich przedsiębiorstw można uznać za porównywalną ${ }^{14}$. Generalnie sektor ten w sposób ciągły rozwija swoją liczebność od 2010 roku. Wolumen małych przedsiębiorstwa wzrosły w 2012 roku o prawie 3,8\% r/r, podobnie jak w latach wcześniejszych (odpowiednio 4,8\% r/r w 2010 r., 4,6\% r/r w 2011 r.). Jest to bardzo optymistyczna prognoza (tab. 1).

Tabela 1

Wzrost liczby MSP w Polsce w latach 2006-2012 (w \%)

\begin{tabular}{|l|c|c|c|c|c|c|c|}
\hline Lata & 2006 & 2007 & 2008 & 2009 & 2010 & 2011 & 2012 \\
\hline MSP & 2,27 & 3,62 & 4,81 & $-10,15$ & 3,18 & 3,36 & 0,58 \\
\hline Mikro & 2,34 & 3,64 & 4,36 & $-10,26$ & 3,16 & 3,36 & 0,50 \\
\hline Małe & $-0,65$ & 2,16 & 21,67 & $-8,70$ & 4,79 & 4,58 & 3,77 \\
\hline Średnie & 3,19 & 5,06 & 5,66 & $-3,18$ & 0,21 & $-0,15$ & $-2,11$ \\
\hline
\end{tabular}

Źródło: opracowanie własne na podstawie danych GUS.

${ }^{12}$ Dane dotyczą sekcji B-J, L-N, P-S PKD 2007. Liczba osób fizycznych: 1643 288, prawnych: 151655 .

${ }^{13}$ Francja - dane Eurostat z 2011 r.

${ }^{14} \mathrm{~W}$ Polsce jest mniej średnich przedsiębiorstw niż w UE-28 o $0,14 \%$. 


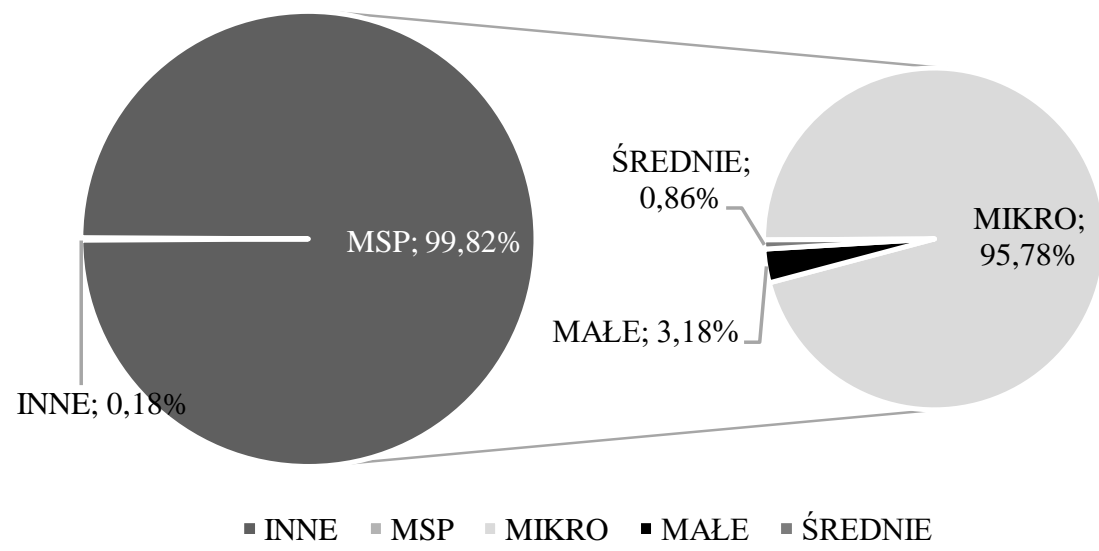

Rysunek 5. Liczba przedsiębiorstw aktywnych w Polsce w 2014 roku

Źródło: opracowanie własne na podstawie danych PARP.

Struktura zatrudnienia Polski pokrywa się z udziałem liczby zatrudnionych osób w UE-28, jednak wytwarzane przez podsektory wartości dodane, znacząco odbiegają od średniej unijnej. MSP w Polsce wytwarza 48,5\% wartość dodanej brutto, z czego najwięcej mikroprzedsiębiorstwa - 29,7\%, małe przedsiębiorstwa zaledwie 7,8\% (o 10,4\% mniej niż średnio w UE-28), średnie firmy - $11 \%$ (odpowiednio: mniej o 7,5\%) (rys. 6).

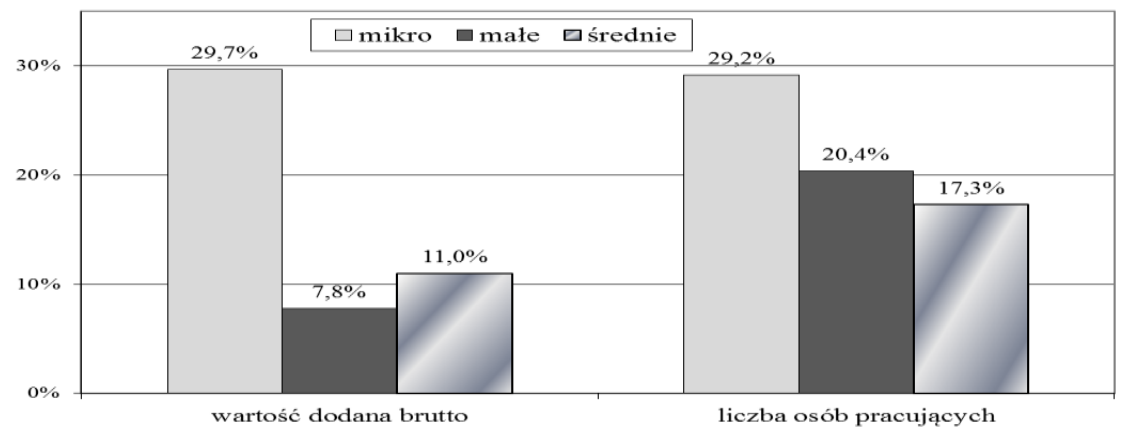

Rysunek 6. Udział wartości dodanej i liczby zatrudnionych osób w MSP w Polsce w 2014 roku

Źródło: opracowanie własne na podstawie danych GUS.

Prezentowane dane warto przeanalizować z punktu widzenia osiąganej efektywności na jednego zatrudnionego z podziałem na sektory w dłuższym okresie, sprawdzając tendencje oraz wpływ efektywności na uzyskiwane wyniki finansowe, decydujące o rozwoju sektora małych i średnich przedsiębiorstw w poszczególnych krajach. 


\section{Udział liczby zatrudnionych i wartości dodanej w poszczególnych branżach działalności}

Państwa unijne preferują działalność gospodarczą w sekcji handlu hurtowego i sprzedaży detalicznej, notując w 2014 roku najwyższe wskaźniki zarówno wśród liczby zatrudnionych osób, jak i wartości dodanej (odpowiednio: $26 \%$ i $22 \%$ ). Pozostałe sekcje uznane za wiodące w środowisku MSP, również zajmują kolejne początkowe miejsca w statystykach, z wyjątkiem wartości dodanej wytwarzanej przez sekcję działalności gospodarczej związanej z zakwaterowaniem i usługami gastronomicznymi, która wytwarza 5\% wartości dodanej całego sektora małych i średnich przedsiębiorstw (po: administracji $-7 \%$, transporcie $-6 \%$, działalności związanej z obsługą rynku nieruchomości - 6\%, i sekcją informacji i komunikacji - 6\%) (rys. 7). W przedsiębiorstwach aktywnych w 2014 roku, branże wiodące zatrudniały $79 \%$ populacji unijnej, wytwarzając $71 \%$ wartości dodanej.

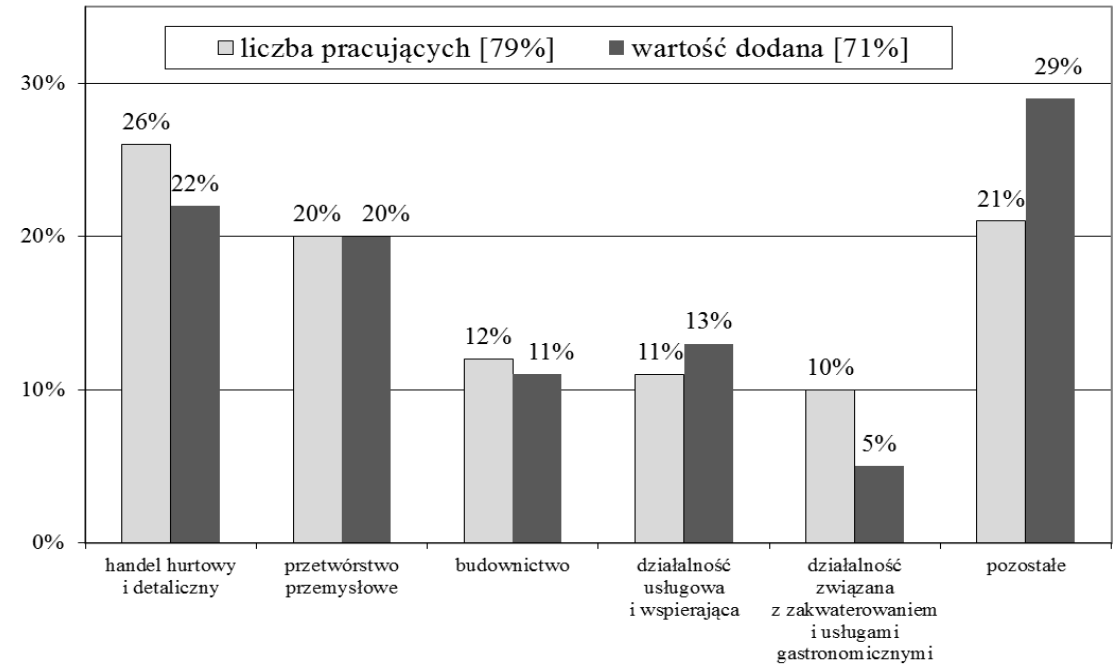

Rysunek 7. Liczba pracujących i wartość dodana wśród przedsiębiorstw aktywnych sektora MSP UE-28 w 2014 roku

Źródło: opracowanie własne na podstawie danych Komisji Europejskiej.

Największy udział zatrudnienia i wartości dodanej wśród mikro, małych i średnich przedsiębiorstw został osiągnięty w 2014 roku w branży budownictwo (odpowiednie: $88 \%$ i $82 \%$ ). Udział powyżej $80 \%$ zatrudnionych w całej branży został zarejestrowany w UE-28 w sekcji działalności związanej z zakwaterowaniem i usługami gastronomicznymi, a także działalności usługowej i wspierającej biznes (odpowiednio: 83\% i 82\%). Udział wytworzonej wartości dodanej $\mathrm{w}$ tym samym okresie również należy do wymie- 
nionych dwóch branż (77\% udział w każdej), do której dołącza sekcja handlu hurtowego i detalicznego (68\% udział) (rys. 8).

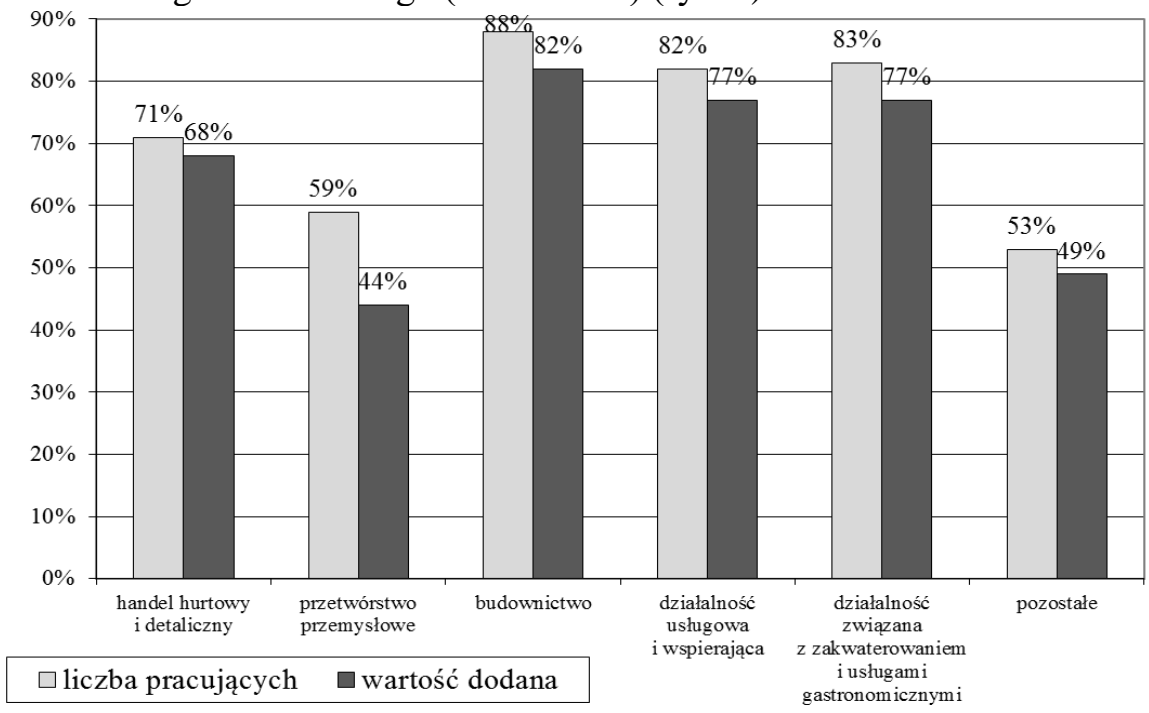

Rysunek 8. Udział liczby pracujących i wartości dodanej w MSP UE-28 w 2014 roku

Źródło: opracowanie własne na podstawie danych Komisji Europejskiej.

Zaznaczyć należy, że wśród branż pozostałych najbardziej wyróżnia się działalność związana $\mathrm{z}$ obsługą rynku nieruchomościami, która osiągnęła wewnątrz tego podziału $88 \%$ udział zatrudnienia i $85 \%$ udział wartości dodanej.

W relacji z 2008 roku, nastąpił zauważalny, dwuprocentowy spadek zatrudnienia $\mathrm{w}$ branżach przetwórstwa przemysłowego i w budownictwie. W tym czasie ich wkład w wartość dodaną zmniejszył się odpowiednio o 1\% i 3\%. Większą popularność zanotowały sektory działalności usługowej oraz związanej z zakwaterowaniem i usługami gastronomicznymi, ponieważ swój udział i wartości zwiększyły zarówno w przypadku liczby zatrudnianych osób, jak i wartości dodanej (odpowiednio: 1\%, 1\%; 2\%,1\%) (GUS, 2015).

Mikroprzedsiębiorstwa i małe firmy działając na terenie UE-28 głównie odnoszą sukcesy w branży hurtowej i sprzedaży detalicznej. Średni przedsiębiorcy pod względem tych dwóch wskaźników najlepiej rozwijają się w branży przetwórstwa przemysłowego ${ }^{15}$.

\footnotetext{
${ }^{15}$ Mikroprzedsiębiorstwa zatrudniają najmniej ludzi w sektorze związanym z zakwaterowaniem i usługami gastronomicznymi oraz $\mathrm{w}$ przetwórstwie przemysłowym; małe firmy w działalności usługowej oraz związanej z zakwaterowaniem i usługami gastronomicznymi; średnie w branży zakwaterowania i usług gastronomicznych.
} 
W Polsce liczba zatrudnionych osób w poszczególnych wiodących strukturach branżowych jest bardzo stabilna (rys. 9). Znacząco jednak odbiega od unijnej. Wiodącą branżą w kraju jest przetwórstwo przemysłowe, które zatrudnia o ponad 6\% więcej osób niż w UE-28. Tendencja zniżkowa odnotowana w sektorze budownictwo jest niższa od unijnej o blisko $3 \%$. $\mathrm{Na}$ szczególną uwagę zasługuje sektor działalności usługowej, który w Polsce, mimo że rośnie, najbardziej odbiega od statystyk unijnych (różnica wynosi ponad 8\%) (GUS, 2014).

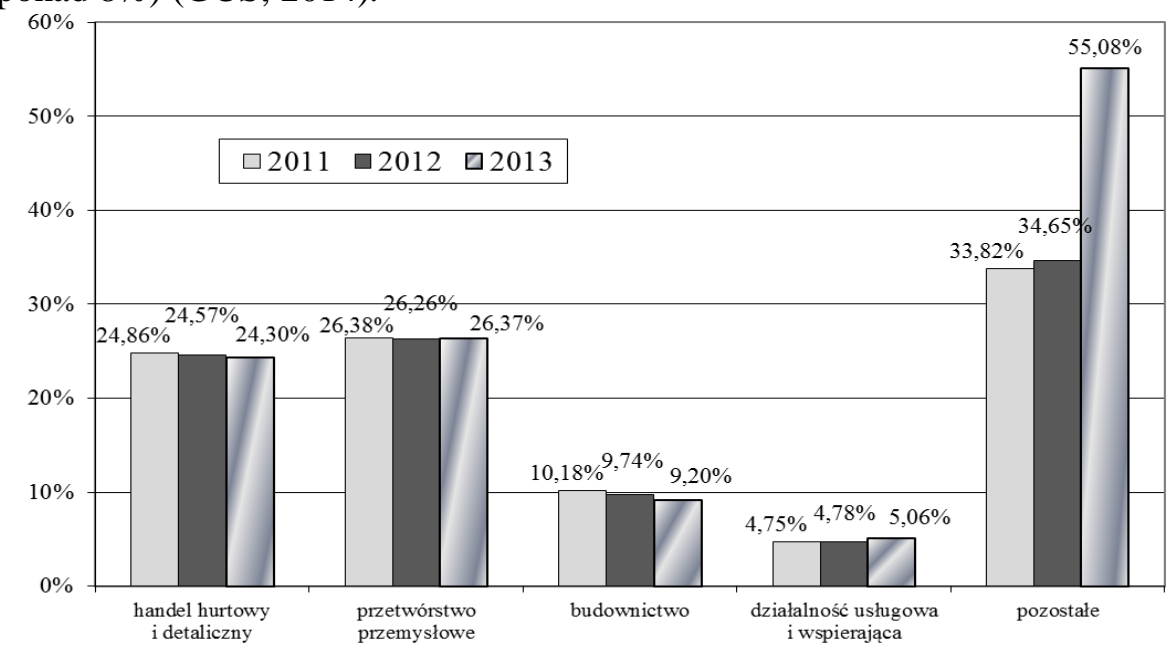

Rysunek 9. Liczba pracujących według struktur branżowych w MSP w latach 2011-2012

Źródło: opracowanie własne na podstawie danych GUS, Małecka, 2015a.

\section{Podsumowanie}

Coraz częściej tematem badań staje się internacjonalizacja przedsiębiorstw, która dotyka bezpośrednio sektor MSP szczególnie ze względu na liczę osób, którym daje zatrudnienie. Tempo umiędzynarodowiania jest wyraźne, mimo że małe i średnie przedsiębiorstwa nie mają strategii dotyczącej tego obszaru działalności. Już co piąte spośród małych i średnich przedsiębiorstw w Polsce rozwija się w tym obszarze, dowodząc dużej elastyczności, szybszej reakcji na zmiany i adaptacji do potrzeb rynkowych, zbliżając w coraz szerszym zakresie wskaźniki bilansów finansowych, do wartości reprezentowanych przez sektor MSP w UE-28.

Zgodnie z danymi raportu sporządzonego na zlecenie Komisji Europejskiej, 99,8\% wszystkich przedsiębiorstw niefinansowych działających na terenie Unii Europejskiej w praktyce oznacza usytuowanie średnio pięciu 
przedsiębiorstw reprezentujących tę grupę, na każdym $\mathrm{km}^{2}$ powierzchni UE28, gdzie w 2014 roku zatrudniano 90 mln ludzi, co stanowi 67\% wszystkich zatrudnionych, generujących 58\% wartości dodanej Unii. Statystyki wykazały, że w 2014 roku przybyło 3,3\% przedsiębiorstw sektora MSP, które zatrudniając o 1,2\% więcej ludzi, zwiększyły o 1,6\% wartość dodaną w relacji z rokiem poprzednim. Polskie wartości wskaźników coraz bardziej przypominają unijne, jednak wewnątrz poszczególnych sektorów działalności odmiennie rozkłada się liczba zatrudnianych osób, a małe przedsiębiorstwa wytwarzają o 10,4\% mniej wartości dodanej niż unijne. Wzrosty w sektorze, w zakresie analizowanych - liczby przedsiębiorstw i osiąganych wartości dodanych dowodzą makroekonomicznego znaczenia polskiego MSP, wpływającego bezpośrednio na poziom europejskiego biznesu.

\section{Bibliografia}

Bielawska, A. (2001). Podstawy finansów przedsiębiorstwa. Szczecin: Wydawnictwo Zachodniopomorskiej Szkoły Biznesu.

Bielawska, A. (2005). Wyjaśnienie trudności nowo powstających przedsiębiorstw w dostępie

do kredytów jako przejaw realizacji teorii asymetrii informacji. W: A. Bielawska (red.), Uwarunkowania rynkowe rozwoju mikro i matych przedsiębiorstw. Szczecin: Wydawnictwo Naukowe Uniwersytetu Szczecińskiego.

Brealey, R.A. (1999). Podstawy finansowania przedsiębiorstw. Warszawa: Wydawnictwo Naukowe PWN.

Churchill, N.C., Lewis, V.L. (1983). The five Stages of Small Business Growth. Harvard Business Review, 63 (3). Pobrano z: https://hbr.org/1983/05/the-five-stages-of-smallbusiness- growth.

Dębski, W. (2014). Rynek finansowy i jego mechanizmy. Warszawa: Wydawnictwo Naukowe PWN.

Duliniec, A. (2011). Struktura i koszt kapitalu w przedsiębiorstwie. Warszawa: Wydawnictwo Naukowe PWN.

Grzywacz, J. (2012). Kapitat w przedsiębiorstwie i jego struktura. Warszawa: Oficyna Wydawnicza Szkoły Głównej Handlowej.

[GUS] (2013). Działalność przedsiębiorstw niefinansowych w 2012 r. Warszawa: Zakład Wydawnictw Statystycznych.

[GUS] (2015). Powierzchnia i ludzkość w przekroju terytorialnym w $2015 \mathrm{r}$. Warszawa: Zakład Wydawnictw Statystycznych.

Jaworski, J. (2010). Teoria i praktyka zarzadzania finansami przedsiębiorstw. Warszawa: CeDeWu.PL.

Kołosowska, B. (2013). Finansowanie sektora matych i średnich przedsiębiorstw ze źródet pozabankowych. Warszawa: CeDeWu.pl.

Łuczka, T. (2001). Kapital obcy $w$ matym $i$ średnim przedsiębiorstwie. Wybrane aspekty mikro- i makroekonomiczne. Warszawa: Wydawnictwo Naukowe PWN.

Łuczka, T. (2013). Makro- $i$ mikroekonomiczne determinanty struktur kapitału $w$ matych $i$ średnich przedsiębiorstwach. Poznań: Wydawnictwo Politechniki Poznańskiej.

Łukasik, G. (2010). Strategie finansowania rozwoju współczesnych przedsiębiorstw. Katowice: Prace Naukowe UE w Katowicach.

Małecka, J. (2015a). Giełda Papierów Wartościowych w Warszawie jako potencjalne źródło finansowania małych i średnich przedsiębiorstw. W: Bielawska A. (red.), Uwarunko- 
wania rynkowe rozwoju mikro, matych i średnich przedsiębiorstw; Mikrofirma 2015 (496-507). Szczecin: Wydawnictwo Naukowe Uniwersytetu Szczecińskiego.

Małecka, J. (2015b). Economic condition of legal persons in the SME sector - potential participants of the capital market in Poland. W: M. Starnawska (red.), Social, innovative and financial dimensions of enterprising organizations. Gdańsk: Gdańsk University of Technology.

Modigliani, F., Miller, M.H. (1958). The Cost of Capital Corporation Finance and the Theory of Investment. American Economic Review, 48 (3). Pobrano z: http://dx.doi.org/ $10.2307 / 1809766$.

Muller, P., Caliandro, C., Peycheva, V., Gagliardi, D., Marzocchi, Ch., Ramlogan, R., Cox, D. (2015). Annual Report on European SMSs 2014/2015. SMSs start hiring again. Karen Hope Editor, for the European Commision.

[NBP] (2015). Raport o inflacji. Warszawa: NBP.

[PARP] (2013). Raport o stanie matych $i$ średnich przedsiębiorstw w Polsce $w$ latach 20112012. Warszawa: PARP.

[PARP] (2015). Raport o stanie matych i średnich przedsiębiorstw w Polsce w latach 20132014. Warszawa: PARP.

Quinn, R.E., Cameron, K. (1983). Organizational Life Cycle and Shifting Criteria of Effectiveness: Some Preliminary Evidence, Management Science, 29 (1). Pobrano z: http:// www.jstor.org/stable/2631164

Scott, M., Bruce, R. (1987). Five Stages of Growth in Small Business, Long Range Planning, 20 (2). Pobrano z: http://citeseerx.ist.psu.edu/viewdoc/download?doi=10.1.1.462.4083 \&rep $=$ rep $1 \&$ type $=$ pdf

[UKNF] (2013). Raport o sytuacji banków w $2012 r$. Warszawa: UKNF.

\section{Employment and Value Added in Small and Medium-Sized Enterprises in Poland and the European Union}

Keywords: SME, firm size, employment, value added, EU, Poland

Summary. This article attempts to present Polish micro, small and medium-sized enterprises as compared to the situation of entrepreneurs operating in the European Union countries. When seen from the macroeconomic point of view, the role and importance of the entire SME sector are still growing. Poland is more and more dynamically and effectively achieving average EU-28 indicators. SMEs contribution to the GDP, constant fluctuations of their number and productivity and growing international activity result in increasingly detailed analyses that allow for determining directions of development of individual sectors and companies of this size. The SME sector becomes particularly significant when we examine the number of SME employees and the value added that is generated by them, namely more than 6 million out of 9 million workers in the Polish economy. This article presents the development of SME employment and value added in the European Union and Poland in 2014.

Translated by Joanna Matecka

\section{Cytowanie}

Małecka, J. (2016). Zatrudnienie i wartość dodana w małych i średnich przedsiębiorstwach w Polsce i Unii Europejskiej. Marketing i Zarządzanie, 2 (43), 117-129. 